\title{
FIGURATIVE LANGUAGE IN TRANSLATION OF TAIWANESE COMMERCIAL ADVERTISEMENT
}

\author{
Elena L. Yakovleva \\ Ph. D., Assistant Professor in the Department of English Language \\ Wenzao Ursuline University of Languages \\ 900, Mintzu 1 ${ }^{\text {st }}$ Rd., Kaohsiung, 80793, Taiwan. elena.yakovleva75@gmail.com
}

ORCID: http://orcid.org/0000-0002-8485-5860

Submitted 03.02.2020

Просьба ссылаться на эту статью в русскоязычных источниках следующим образом:

Yakovleva E. L. Figurative Language in Translation of Taiwanese Commercial Advertisement // Вестник Пермского университета. Российская и зарубежная филология. 2020. Т. 12, вып. 2. С. 63-71. doi 10.17072/2073-6681-20202-63-71

Please cite this article in English as:

Yakovleva E. L. Figurative Language in Translation of Taiwanese Commercial Advertisement. Vestnik Permskogo universiteta. Rossiyskaya i zarubezhnaya filologiya [Perm University Herald. Russian and Foreign Philology], 2020, vol. 12, issue 2, pp. 63-71. doi 10.17072/2073-6681-2020-2-63-71 (In Russ.)

This study is an analysis of Taiwanese companies' promotional texts. The products advertised include computer programs and games, high-tech computer equipment, machinery, spare parts for cars, LEDs, cosmetics, and other goods for distribution in Russian-speaking markets of CIS countries. Therefore, the target language (TL) of translation was Russian. The researcher has been collecting Taiwanese promotional translation texts for over ten years. This research utilizes an empirical inductive method and is supported by relevant translation theories such as Skopostheorie by Vermeer [1989] and re-contextualization theory by House [2008]. The article analyzes the difficulties in translating promotional materials from Chinese as the source language (SL) into English as the intermediary language (IL) and then from English into Russian as the target language (TL). The article demonstrates how an intercultural competence can be developed in doing international business when there are language barriers. Data analysis has revealed that Taiwanese promotional texts frequently use epithets, metaphors, idioms, sayings and proverbs which are integral to Chinese culture and speech. This type of figurative language is often difficult to translate due to cultural differences and lack of equivalent meanings or insufficient encyclopedic knowledge. In order to accurately convey the essence of the text translated, deliver effective promotional materials, and maintain the attractiveness of the product being advertised for the companies and their end users, a translator must become an intercultural mediator. This research will provide a greater insight into the interlingual and intercultural challenges and offer translation strategies that can assist translators in producing more accurate translations and maintaining more positive intercultural relations between Taiwan and other countries. This intercultural research will contribute to a greater understanding of how Taiwanese products can be better promoted in Russian-speaking markets.

Key words: cultural intermediary; domestication; encyclopedic (interdisciplinary) knowledge; equivalence; foreignization; re-contextualization theory; Skopostheorie; translational creativity.

\section{Introduction}

Taiwanese companies must translate promotional materials in order to advertise their products in international markets. This requires the translator to adopt the correct strategy that will best promote Taiwan's products internationally. Taiwanese companies such as Acer and Asus computers, Foxconn semi-conductors, Gmor rubber and Ruby Rose cosmetics are already world famous. However, based on the author's experience, foods, teas, intellectual toys, environmental products, LEDs and high-tech products are now increasingly in need of promotional translations. Detailed promotional materials must be presented professionally in the TL and appeal to 
consumers in the various countries, where the products will be sold. Yakovleva [2016] found that product translation must be consumer-friendly and contribute to the products' success in the targeted languages, especially in the countries where English is not common such as France or Russia.

Taiwanese companies often ask the translation agencies to translate the description of their products to promote them on the international stage. For the translation, the companies provide the products' description with ingredients or raw materials used or user's manuals. Their commercial texts may also contain advertising slogans of the company or their product. These often include Chinese legends, historical characters, proverbs, sayings or idioms. This type of figurative language can impede the transfer of meaning from the SL into the TL, which may be translated into two or sometimes three languages, all of which have diverse cultures. Therefore, the translator must make the original idea comprehensible in the target language and culture.

Another challenge that the translator faces is that the translation does not come directly from the SL such as Chinese and is usually translated into the IL such as English before it is then translated into the TL. In Taiwan, English is usually the chosen intermediary as many businesses are already established in English-speaking countries. Since English is the international language, many Taiwanese companies have already created websites in English. Therefore, the source language (SL) risks losing its original meaning when it is translated into the intermediary language (IL) and then finally into the target language (TL): $\mathrm{SL} \rightarrow \mathrm{IL} \rightarrow \mathrm{TL}$.

\section{Objective and Methodology}

This article provides deeper insight into Taiwanese business culture by illustrating how Taiwanese companies use figurative language with metaphors, proverbs, sayings and idioms etc. when developing their promotional materials. It also demonstrates how the author can carry out the role of cultural mediator by either utilizing a cultural equivalent or provide explanations that can be culturally understood in the TL.

Data was derived from the author's thirteen years of translation experience with about one hundred files which are mainly Chinese as the SL, with English as the IL and Russian and German as TLs. It is to mention that some of Taiwan's translation companies insist on not using any sort of translation technology; however, Google translate is highly recommended as a tool for translators. It saves time and was used while translating the examples of this research data analysis. Translation software can be very helpful in translating the SL into the TL. It is imperative that the translator revises the text by se- lecting precise words, refining the language and inserting corresponding cultural realms into the TL. The Russian equivalent of Google translate is slovari.yandex.ru, which was often utilized when translating colloquial wording or idioms into Russian.

This research examines many cultural aspects that translator faces when attempting to translate Taiwanese companies' promotional materials in the international market. The content is based on the author's own translation experiences (usually from English into Russian and German). These include dealing with the Taiwanese cultural context that is often present and so the content must be culturally understood in the target country.

This research utilizes qualitative inductive practice-oriented investigation methodology, where the author provides a thorough analysis and generalizes the results. The empirical analysis applies translation theories mentioned below, whereas the translator acts as a cultural mediator by using a "cultural filter". This will then construct the perfect combination of linguistic and cultural mediation, which is paramount for any substantial marketing strategy and multilingual translation. This type of detailed analysis fundamentally links language and culture within the translation process and provides multi-faceted perspectives that can increase the success of a multinational business.

\section{Theoretical framework}

Chinese culture is rich in stories, legends, metaphors, sayings, idioms and proverbs that are integrated into written and spoken communication [cf. Xiao 2016]. Chinese speakers often apply them to promotional materials that are going to be translated into other languages. This can potentially bring about confusion or cross-cultural misunderstandings. As shown below, some Taiwanese companies even include such cultural nuances in their product descriptions. If translations are not carried out meticulously, this type of figurative language could cause confusion and will not be understood by end consumers. Sometimes, the equivalent meaning can be found in the IL (English), which brings a more authentic meaning to the translation. However, often these texts are so culturally specific that they either require a more detailed explanation or understanding of a TL equivalent. This makes it challenging to maintain concise meanings when Taiwanese companies use culturally specific, figurative language that has come from the original Chinese text and then translated into English and then into Russian for the Russian-speaking markets.

Since cultural awareness is crucial for advertising that often includes metaphors and idioms in its SL, Skopostheorie by Hans J. Vermeer [1989] will be applied in this study. In commercial translation, 
"phonetic appeal, suitable meaning, socio-cultural adaptation, and consumer acceptance" is important for products to reach target consumers from different cultures and be successful in international markets [cf. Sang \& Zhang 2008: 225ff]. Therefore, it is clearly important to take into account the linguistic and cultural aspects of promotional materials. This functionalist approach emphasizes the translation of the targeted text, with the source text being of secondary importance [Sang \& Zhang 2008: 232]. Vermeer [1989: 14] found that in order for a company to achieve success in their marketing, the translator needs to fully understand the cultural conditions of the source context. Since the culture and language is a dynamic process, the translator needs to decide what can be made comprehensible and acceptable, even when working with taboo topics [cf. Sang \& Zhang 2008: 235]. He and Xiao [2003: 131] also asserted that texts should suit local markets linguistically and culturally and meet international legalities, while still conveying concise product information.

House's [2008] translation theory coined the terms "Re-contextualisation and the Third Space phenomenon", which also emphasizes linguistic-cultural relativeness through the following methodology:

- Integrate extra-linguistic world which is perceived differently by speakers of the L1 and L2

- Use translator's creativity

- Bridge juxtaposed language and cultural gaps

- Use functional pragmatic equivalence of converted translation from the original text when it appears in the L2 context

- Identify equivalences while maintaining the context

- Manipulate the language in order to satisfy any existing cultural filters.

Benjamin [1923/1977] and Bhabha [2000] both found that in translation, untranslatability is a common phenomenon. He and Xiao [2003: 135] figured out that every language has its own unique lexicon, of which its endemic existence can only be found in that specific culture.

M. Baker [1992] categorized translation into four levels of equivalence:

1. Word Level and above Word Level Equivalence (meaning single words and expressions may require combination of words for an equivalent translation)

2. Grammatical Equivalence (number, person and gender, tense and other grammatical aspect and voice congruence that often vary across languages)

3. Textual Equivalence (word order and cohesion variations)

4. Pragmatic Equivalence (variations in cultural communication and context).

In regard to pragmatic equivalence, Cuellar [2002] grants the translator artistic license to identify con- textual equivalence that may not already be in existence and therefore needs to be formulated by the translator. This often includes metaphors, sayings and idioms. R. Jakobson's [1959: 238] research applied the term 'creative transposition' to interlingual translation, where cultural and verbal cues were interpreted in other languages.

Besides linguistic and cultural competence, the translator may also need to provide encyclopaedic knowledge to the context. According to Sperber and Wilson's [1986] Relevance Theory which was later also emphasized by A. Vermes [2007], assumptions are sometimes required for some contexts, particularly when the translator is not given detailed information and provided with only textual implications. Vermes [2007: 132] established that sometimes translators could utilize encyclopaedic knowledge in order to interpret and explain unwritten information, when the context may not be immediately obvious to the target audience. These types of inferential interpretations and cultural specifics that don't exist in the target culture must be carried out by the translator, who must be granted relative translational freedom and creativity, in order to achieve greater contextual accuracy [Sternberg 1999; Wills 1996 in S. E. Pommer 2008]. S. E. Pommer [2008: 356] pointed out that there were three aspects of creativity, which included novelty, appropriateness and acceptance. Sternberg [1999: 433] also proposed three methods of thinking: synthetic thinking of new and interesting ideas, critical appraisal and analytical and practical thinking that identifies possible solutions and innovative ideas that will be comprehensible for the target audience. To sum up, the translator must apply appropriate critical thinking and creativity in order to provide an effective translation. This can be particularly applied to translations that include figurative language (e. g. metaphors, idioms, proverbs, sayings and other colloquialisms) that are required for various types of literature and promotional materials.

Leonardi [2010] and Vermes [2007] also warn that the translator must avoid inconsistency and superficiality in translation. Translations should not be minimalized to simply deal with necessary encyclopaedic assumptions that appear within cultural contexts [Vermes 2007: 139]. The translator must understand the text in its entirety; otherwise the source's context will not be completely understood by the target reader. The translator must be fully aware of the fact that he is the direct interpreter, while the target reader becomes the secondary interpreter, who is dependent on the translator's accuracy [Vermes 2007: 139]. In order to avoid superficiality, the translator must find a way to logically transfer the meanings of metaphors, idioms, sayings and proverbs, when no direct translations are available. 
However, translations must still occur within the parameters of the chosen interpretation strategy and at least one term or cultural nuance must be maintained from the original context. Vermes [2007] claimed that in order to avoid confusion and effectively integrate linguistic and cultural mediation, the translator should produce a text that is easily interpreted by the target reader. In this case, both foreignising (the strategy of retaining information from the source text and preserving its meaning in the target text) and / or domesticating (the strategy of making a source text closely conform to the TL) translation strategies could be applied [Vermes 2007; Bhabha 2000]. The translator must introduce new aspects such as explanations of the source's culture, words or phrases that may not exist in the target culture. In this research, both strategies will be utilized and are often interwoven.

Pommer [2008] coined three strategies to carry out translation creativity:

1. Integrational creativity of new ideas that are subtly tied to the old ones

2. Exploratory creativity that includes knowledge of relevant rules

3. Transformational creativity and significant adaptation.

She pointed out that one translation can combine several strategies in order to increase comprehension and effectiveness. Pommer [2008: 364] also emphasized the impact of language and culture on creativity and how the translator is textually limited, therefore stressing that the translator must be granted a margin of creativity, even in legal translation. Therefore, the translator must not only be creative but also possess the ability to identify and apply various translation solutions [cf. Pommer 2008: 359]. Wills [1996] stated that creativity is a domainspecific attribute and is therefore pertinent to some translations. The degree to which creativity could be utilized varies in terms of types of translation, including various literature genres, commercial and promotional materials, religious publications and technical or legal documents. An acceptable amount of creativity that appears in the translation for the target reader should be congruent with the contents of the source, yet provide corresponding encyclopaedic knowledge and cultural specifications. This therefore increases the necessity for the translator to possess excellent critical thinking skills and a wide multi-disciplinary knowledge in order to provide accurate translations [cf. Forstner 2005 in Pommer 2008: 363].

Linguistic-cultural interdependence is central to most modern translation theories. The term "cultural hybridity" coined by Bhabha [2000] is integral when developing translation processes that combine elements of SL and TL. Benjamin [1996/2004: 253ff.] metaphorically likened translation as circular tangent, where the original text starts out at one single point but later is carried out its own way.

Belloc [1931] also depicted how to effectively carry out translation practices by presenting six principles:

1. Regard the work as an integral unit that is translated in sections

2. Decode idiom by idiom

3. Translate intention by intention

4. Avoid les faux amis (false cognats)

5. Alter courageously

6. Never overstate.

In conclusion, translation is a fluid process, which creates a new and corresponding meaning in the TL. The translator must consider both languages' stylistic and idiomatic norms, as well as their cultural nuances. The translator must be granted liberty throughout the translation process, in order to adequately produce genuine context [cf. Haque 2012: 108].

\section{Data analysis}

This data is generally classified into three figurative speech categories:

I. Use of epithets

II. Use of metaphors

III. Use of proverbs, idioms or culturally specific terms.

Chinese as the SL often uses vivid and expressive language for its promotional materials and combines several meanings into one text.

Before analyzing the following examples it is necessary to mention that the original English translation was provided by the company and has not been altered.

Exp. 1) A Taiwanese manufacturer of PCs for games wrote:

Engl. The tòu 2.0 instills a whole new sense of pride and mystique to the PC Master Race Demonstrate to your friends, colleagues or pets the illuminated internal structure. The breathtaking mirrored chassis reveals the PC's hardware by simply sliding your finger to activate on/off the specialized lighting.

Russ. tòu 2.0 прививает совершенно новое чувство гордости и загадочности для компьютерных мастеров гонок, демонстрируя Вашим друзьям, коллегам или домашним животным освещенную внутреннюю структуру. Захватывающий дух зеркальный корпус раскрывает устройство ПК с помощью простого движения пальцем, чтобы активировать включение / выключение специализированного освещения.

Engl. tòu 2.0 - A New Transparent Aesthetic Signature Chassis

Sensory Gaming Unleashed!

Russ. tòu 2.0 - Новый прозрачный эстетический именной корпус-шасси

Свободная сенсорная игра! 
Three regional language aspects become apparent in this example including strong epithets such as 'breathtaking' and 'unleashed', which was designed to make the product appear more attractive and the advertisement more persuasive. The use of positive and strong adjectives is a common practice in commercials and other types of promotional materials in order to impress consumers and stress the products superior functionality [ref. Yakovleva 2012]. Secondly, "simply sliding your finger" emphasizes the device's ease of use, which also contributes to the product's appeal, particularly for the game's players. However, the third characteristic of demonstrating the device to their pets might not be something that would be understood by Russian consumers. In Taiwanese society, pets (particularly dogs) are equal with humans. In many homes, dogs and cats are treated with respect, care and love. It is common to see the Taiwanese, especially younger people, pushing specially made strollers for dogs, as if they were a baby. However, in most Western societies this would be considered unusual and would not contribute to product appeal. In this case the translator used foreignising translation strategy to introduce this new foreign concept (cf. Bhabha 2000; Vermes 2007).

Exp. 2) A Taiwanese PC power supply unit company put the following on its website:

Engl. All other power supply need step aside as the Commander series from In Win rolls in full force ready for battle. Russ. Все другие источники электропитания должны отступить в сторону перед серией Commander из In Win, которая в полной силе готова конкурировать.

The advertisement strongly implicates that this company is the best manufacturer of PC power supply units and therefore "all others should step aside" and that they are ready to fight a battle with other companies. This is intended to position themselves as the winner. In the Russian translation 'ready for battle' was translated as 'ready for competition' since here the 'battle' metaphor means 'market competition'. The translator decided to use word level equivalence (cf. Baker 1992) and literal meaning since the text didn't provide any more information than it manufactures PCs for video games and that in the Commander Series players can fight.

Exp. 3) A Taiwanese electrical vehicles company wrote:

Engl. Shu says that, with most global carmakers' dream to build intelligent modes of personal mobility since the Pony Express days.

Russ. Шу говорит, что большинство мировых автопроизводителей мечтают создать интеллектуальные режимы личной мобильности со времен Пони Экспресс (Pony Express).
This example requires the readers to utilize their interpretive skills and encyclopaedic knowledge in understanding that the Pony Express was an American mail service that operated from 1860-1861 and delivery was carried out on horseback. The advertisement also implies that after more than a century this company may have finally found an equivalent innovative solution with its electric vehicles. It sounds very impressive.

The examples below clearly illustrate that Taiwanese companies often utilize figurative language in the form of metaphors.

Exp. 4) A Taiwanese online company specializing in an awards program reminds the customers who don't reply to them within four weeks pose following questions:

Engl. Vacation? Computer problems? Have Komodo dragons or alligators taken over your town?

Russ. Отпуск? Проблемы с компьютером? На Ваш город напали комодские вараны или аллигаторы?

Engl. We're glad to help you on your way to earning cash and rewards by sharing your opinions with us. We make it easy for you, this isn't rocket surgery.

Russ. Мы рады помочь Вам в зарабатывании денег и вознаграждений, если Вы поделитесь с нами своим мнением. Мы облегчим Вам задачу, это не так уж сложно.

This company tried to promote its award programs in Germany, Russia and other countries. Its instruction didn't contain any explanation of how points are earned, but only stated how great the program is and how the members can access their money at any ATM in their country. It not only sounded untrustworthy but even suspicious. The story about Komodo dragons and alligators also sounded childish and unrealistic, especially to Westerners where dragons are usually only objects of fairy tales. Adult customers would consider this an exaggeration, which would generate distrust. However, dragon myths are common place in Taiwanese society and dragons are often seen in advertisements. Dragons are also auspicious creatures and behold positive connotations for the Taiwanese and other Asian consumers. Therefore, a foreignising translation strategy was utilized to deal with this concept, which provided the TL with the original context. The many questions that were asked in the advertisement gave rise to indirect connotations. The company was aggressively reminding and requesting gamers to stay active. The metaphor "rocket surgery" (probably meaning "rocket science") insinuates something is complicated or difficult or a process that requires intelligence. As this metaphor is not common in Russian, it was directly translated as 'not very difficult'. This domesticating transla- 
tion strategy was chosen by the translator to provide a more comprehensive input in the TL [cf. Bhabha 2000; Vermes 2007].

Exp. 5) A Taiwanese engineering company claimed:

Engl. Currently we are still coping with teething pains as the smaller members still need technical help from the two leaders.

Russ. В настоящее время мы все еще справляемся с «зубными болями», поскольку более мелкие компании все еще нуждаются в технической помощи от двух лидеров.

A development problem is emphasized through the "teething pains" metaphor. This could be translated easily into other languages as everyone can understand this problem, as babies all over the world cry or feel uncomfortable when they are teething. Despite the difficulties they are experiencing they use the verb 'cope', which implies the company is handling their problematic issues and therefore their company is given a more positive context.

Exp. 6) A Taiwanese LED-manufacturer advertised:

Engl. Also with lighting generally consuming some $30 \%$ of all electricity used, China would be ecointelligent to adopt more energy-efficient lighting as LED, especially when the pace of urbanization in China speeds ahead, a process that inevitably builds more office and retail structures that have a voracious appetite for lighting.

Russ. Учитывая то, что освещение обычно использует около $30 \%$ всего потребляемого электричества, Китай будет более эко-интеллектуален, чтобы использовать более энергоэффективное освещение в качестве светодиодов, особенно когда темпы урбанизации в Китае ускоряются. Это процесс, который неизбежно создает больше офисных и торговых структур, имеющих ненасытный аппетит к освещению.

Engl. The lightening industry in Taiwan needs to develop viable alternatives to better compete against the heavyweights.

Russ. Осветительной промышленности Тайваня необходимо разработать жизнеспособные альтернативы для лучшей конкуренции с тяжеловесами.

Engl. He suggested that China is Taiwan's breadbasket, that Taiwan's LED-lighting manufacturers perhaps have little choice but to rely on the vast China market for its future.

Russ. Он предположил, что Китай является житницей Тайваня, и что у тайваньских производителей светодиодного освещения, возможно, нет иного выбора, кроме как полагаться на огромный китайский рынок в будущем.

Engl. He also believes that Taiwan's LED-lighting manufacturers need the government's assistance to set up distribution channels at home and in China, instead of mere funding, underlining perhaps the shadier side of doing business in China where ethical practice takes a backseat to nepotism, horse-trading and influence-peddling.
Russ. Он также верит в то, что тайваньские производители СИД-освещения нуждаются в поддержке правительства для установления дистрибъютерских каналов дома и в Китае, вместо простого финансирования, подчеркивая возможно более тенистую сторону бизнеса в Китае, где этическая практика занимает скромное положение по отношению к кумовству, политическим махинациям и влиянию на мелкую торговлю.

Here the hyperbolized metaphor 'voracious appetite' definitely indicates that there is a huge demand for LEDs in China's market and in other countries. In Russian it was translated as 'insatiable appetite'. The same idea was also expressed through the metaphor of China being a 'breadbasket' or a good market for Taiwan's LED-lighting manufacturers, which was translated as an easy method for gaining profit. In order to save energy, more energy-saving solutions like LEDs are needed. This was designed to get consumers thinking about energy saving options. The metaphor 'heavyweights' refers to strong competitors and according to this advertisement competitors in the lighting market are equivalent to boxers in the boxing rink. It indicates that the competition is very challenging, but the Taiwanese lighting industry can offer viable alternatives. The following text also describes other difficulties in doing business in China through metaphors like 'backseat' or 'horse-trading' that were translated directly. In this case the metaphors were not used in the TL, making it easier for the Russian reader to comprehend.

Exp. 7) A Taiwanese car-parts manufacturer wrote:

Engl. Another indicator was the heavy foot traffic to the CENS booth, where staff was flooded by visitors asking for Taiwanese supplier information, with such eagerness seen from the first day to the last minute of the event.

Russ. Другим индикатором было большое скопление у стойки CENS, где посетители засыпали сотрудников вопросами насчет информации о тайваньских поставщиках; при этом такой интерес был проявлен с первого дня до последней минуты выставки.

Engl. Taiwan has developed into an innovation and development citadel for advanced, price-competitive auto-electronics systems and parts.

Russ. Тайвань превратился в цитадель новаторства и развития для передовых, конкурентоспособных по цене авто-электронных систем и запчастей.

Here we can see that metaphor is used not only for promoting products, but also for promoting the success of the company. The exhibition was described as having 'heavy foot traffic' and simply translated into Russian as being 'crowded'. The metaphoric phrase 'staff was flooded by visitors' was translated into Russian by using a creative transposition [cf. R. Jakobson 1959] with the choice word being 'bombarded' ('заброшены'). This creat- 
ed impressive and convincing evidence that Taiwanese car-part manufacturers have been tremendously successful. This imagery was further developed when it described the 'heavy foot traffic' as being from 'the first day to the last minute (not the day!)' of the exhibition. The Taiwanese car part manufacturing industry is further promoted with the use of the metaphor 'citadel', which creates the imagery of a fortress, which is built with great strength and a solid foundation. This metaphor was then directly translated into Russian as it also has a positive meaning in Russian society.

Exp. 8) A Taiwanese cosmetic company that treats acne wrote:

Engl. Say goodbye to the shiny oily T-zone on your face!

Russ. Попрощайтесь с блестящей жирной Т-зоной кожи на Вашем лице!

The metaphoric phrase 'Say goodbye' was directly translated into Russian as it was also comprehensible in the target culture as the ultimate solution to eradicate acnes.

Exp. 9) Engl. This maker is known for developing innovative products, without much fanfare, and is headquartered in Pali, New Taipei City in northern Taiwan.

Russ. Этот производитель известен разработками новаторских изделий даже без особых фанфар. Основной офис компании размещен в Пали, Новый Тайбэй на севере Тайваня.

This translation is problematic for two reasons, first because there are two different ideas presented in one sentence. This often occurs in Chinese writing; however in the TL, these types of sentences should be split into two. Secondly, the metaphor 'without much fanfare' is vague and even controversial. 'With fanfare' means to have great fame and publicity, therefore it is unclear whether the company is famous or not. It could also be interpreted that even without fanfare the company is still known. By adding these particles, the Russian translation becomes increasingly clarified.

The use of phrasal verbs or idioms is also a popular tool that is used by Taiwanese companies to attract customers' attention. The following provides examples of this:

Exp. 10) A high-tech company wrote:

Engl. We're supporting 11 different languages and hundreds of offers for the BETA program alone, so bear with us as we iron out kinks and address usability issues. We're fixing bugs, testing significant changes to the workflow, and adding many new features as we speak.

Russ. Мы поддерживаем 11 различных языков и сотни предложений только для программы BETA, так что будьте терпеливы с нами, когда мы устраняем неполадки и решаем вопросы использо- вания. Мы исправляем ошибки, тестируем существенные изменения в рабочем процессе и добавляем множество новых функций, как мы и говорим.

The synonymous idioms of 'ironing out kinks' and 'fixing bugs' means to 'solve a problem'. This type of informal language is quite common in the virtual world; however, in Russian it was literally translated as 'solve the problem' for easier comprehension.

Exp. 11) A Taiwanese video game company wrote: Engl. Pump up your wallet or your purse.

Russ. Пополните Ваш кошелек.

It can be considered superfluous to use a wallet and a purse to differentiate between a man and a woman. Therefore, in Russian it was translated as one word. In order to shorten the translation, the metaphor 'pump up your pocket' could be used. The phrasal verb 'to pump up' exaggerates the amount of money which could be earned, but it impresses the customers.

The use of proverbs is common in Taiwanese companies' advertising text, which is probably due to the fact that Chinese language is so rich in proverbs. This may impede the translation due to the lack of appropriate proverbial language in the TL.

Exp. 12)

Engl. The timeless adage "when the going gets tough, the tough get busy" certainly applies to three Taiwanese OA furniture parts makers.

Russ. Вневременная поговорка «когда становится трудно, то сильные действуют», безусловно, относится к трем тайваньским производителям мебели.

Applying a domestication translation strategy, the English proverb was descriptively translated and in order to convey an equivalent meaning in Russian it was translated 'when times get tough, strong people will act'. The Russian equivalent "сильные духом трудностей не боятся" (Engl. 'people with a strong spirit do not fear challenges') could also be applied in the TL.

Exp. 13) Engl. Unfortunately e-management is as rare in Taiwan's hand tool sector as a bookkeeper in the line with a degree from the Wharton School of Business; even rarer still would be the establishment of an in-house computer engineering division.

Russ. K сожалению, электронное управление встречается в тайваньском секторе ручного инструмента так же редко, как бухгалтер с дипломом Уортонской школы бизнеса; еще более редким было бы создание собственного подразделения компьютерной инженерии.

This informative textual style deals with how Taiwanese companies get published in international business magazines, in order to promote themselves in foreign markets. It contains details that are un- 
known to many consumers. The Wharton School of Business doesn't mean much to most European consumers and only if they research it on the internet, they will find that the Wharton School of Business is part of the University of Pennsylvania, which is considered the world's most comprehensive source of business knowledge. After obtaining this information in its entirety, it is understandable that Taiwan hasn't had many business people who have graduated from this famous school. Although, the school's name should be translated directly, it should be explained for consumers who do not know what it is. In the introduction, the reader should focus on the company's profile and should not be impeded with less relevant and distractive factors.

\section{Conclusion}

Both translator and companies must understand the importance of cultural values within the TL and identify more effective ways to transfer cultural salience from SLs into TLs. The translation process often simplifies phrases, especially when the SL contains metaphors, idioms, sayings and proverbs that are paraphrased or omitted in the TL. Foreignising and domesticating strategies are often used when texts are adapted. Foreignising is used when new terms are adopted or SL concepts are introduced in the TL. Logical assumptions and implications based on the translator's encyclopaedic competence are also crucial for effective and clear translation. The translator must carefully read, interpret and assess the context of the SL and that of the TL. The translator must creatively and adequately maintain the context in the TL. Creativity and understanding of multiple disciplines are crucial when providing effective translations, especially in promotional materials that are rich in figurative language, including expressive epithets, idioms, proverbs, sayings and metaphors etc. Therefore, the translator must be multi-talented, competent, responsible and flexible in order to provide a highly qualitative translation which could contribute to the successful marketing strategy of the company.

\section{References}

Baker M. In Other Words: A Coursebook on Translation. New York, Routledge, 1992. 304 p. (In Eng.)

Belloc H. On Translation. Oxford, Clarendon Press, 1931. 15 p. (In Eng.)

Benjamin W. Selected Writings: The Task of the Translator. Cambridge, MA, Harvard University Press, 1923, 1996/2004, vol. 1, pp. 253-263. (In Eng.)

Bhabha H. How newness enters the world. J. Procter (ed.) Writing Black Britain 1948-1998. An
Interdisciplinary Anthology. Manchester and New York, Manchester University Press, 2000, pp. 300306. (In Eng.)

Cuellar S.B. Equivalence Revisited: A Key Concept in Modern Translation Theory. Forma y Función, 2002, vol. 15, pp. 60-88. (In Eng.)

Haque Z. Translating literary prose: problems and solutions. International Journal of English Linguistics, 2012, vol. 2(6), pp. 97-111. (In Eng.)

$\mathrm{He}$ Ch., Xiao Yu. Brand name translation in China: An overview of practice and theory. Babel, 2003, issue 49(2), pp. 131-148. (In Eng.)

House J. Towards a linguistic theory of translation as re-contextualisation and a Third Space phenomenon. Linguistica Antverpiensia, New Series Themes in Translation Studies, 2008, issue 7, pp. 149-175. (In Eng.)

Jakobson R. On linguistic aspects of translation. R. A. Brower (ed.) On Translation. Cambridge, MA, Harvard University Press, 1959, pp. 232-239. (In Eng.)

Leonardi V. The Role of Pedagogical Translation in Second Language Acquisition: From Theory to Practice. Bern, etc., Lang, 2010. 179 p. (In Eng.)

Pommer S. E. No creativity in legal translation. Babel, 2008, issue 54(4), pp. 355-368. (In Eng.)

Sang J. \& Zhang G. Communication across languages and cultures. A perspective of brand name translation from English to Chinese. Journal of Asian Pacific Communication, 2008, issue 18(2), pp. 225-246. (In Eng.)

Sperber D., Wilson D. Relevance: Communication and Cognition. Oxford, Basil Oxford Blackwell, 1986. 279 p. (In Eng.)

Sternberg R. J. (ed.). Handbook of Creativity. Cambridge, Cambridge University Press, 1999. 502 p. (In Eng.)

Vermeer H.J. Skopos and commission in translational action. A. Chesterman (ed.) Readings in Translation Theory. Helsinki: Oy Finn Lectura, 1989, pp. 173-187. (In Eng.)

Vermes A. The problem of cultural context in translation and translator education. Eger Journal of English Studies, 2007, VII, pp. 129-141. (In Eng.)

Wills W. Knowledge and Skills in Translator Behavior. Amsterdam / Philadelphia, John Benjamins, 1996. 256 p. (In Eng.)

Xiao F. An empirical study of figurative competence of Chinese EFL learners. American Journal of Educational Research, 2016, issue 4(11), pp. 806810. (In Eng.)

Yakovleva E. Functions of attributes in translation of advertisement. International Youth Conference 'Translation as a factor of development of science, technology and sport in the modern world' 
within the Federal special-purpose program 'Scientific and scientific-pedagogical personnel of innovative Russia in the years 2009-2013', Vyatka State University for the Humanities. September 5-6, 2012, pp. 287-289. (In Eng.)
Yakovleva E. The role of a translator as a cultural mediator in the promotion of Taiwanese companies in the post-Soviet area. Perm University Herald. Russian and Foreign Philology, 2016, issue 3(35), pp. 75-84. (In Eng.)

\title{
ФИГУРАТИВНЫЙ ЯЗЫК \\ В ПЕРЕВОДЕ ТАЙВАНЬСКОЙ КОММЕРЧЕСКОЙ РЕКЛАМЫ
}

\author{
Елена Леонидовна Яковлева \\ Ph. D., доцент кафедры английского языка \\ Языковой университет Венцао Урзулин \\ 80793, Тайвань, г. Гаосюн, 1-ая ул. Минцу, 900. elena.yakovleva75@gmail.com \\ ORCID: http://orcid.org/0000-0002-8485-5860 \\ Статья поступила в редакицю 03.02.2020
}

Это исследование представляет собой анализ рекламных текстов тайваньских компаний. Продукция включает компьютерные программы и игры, высокотехнологичное компьютерное оборудование, машинное оборудование, запчасти для автомобилей, светодиоды, косметику и другие товары для распространения на русскоязычных рынках стран СНГ, поэтому выходным языком перевода (TL) был русский язык. Исследователь собирала тексты перевода тайваньской рекламы на протяжении более десяти лет. Это исследование использует эмпирический индуктивный метод и опирается на такие теории перевода как Теория Скопос [Вермеер 1989] и теория реконтекстуализации [Хаус 2008]. В статье анализируются трудности перевода рекламных материалов с китайского языка как исходного (SL) на английский в качестве посреднического языка (IL), а затем с английского на русский как выходной язык (TL). В этой статье исследовано как можно развить межкультурную компетенцию при ведении международного бизнеса, преодолевая языковые барьеры. Анализ данных показал, что в тайваньских рекламных материалах часто используются эпитеты, метафоры, идиомы, поговорки и пословицы, которые являются неотъемлемой частью китайской культуры и речи. Этот тип фигуративного языка нередко трудно перевести из-за культурных различий и отсутствия эквивалентных значений или недостаточных энциклопедических знаний. Чтобы точно передать суть переводимого текста, предоставить эффективные рекламные материалы и сохранить привлекательность товара для компаний и их конечных потребителей, переводчик должен стать межкультурным посредником. Это исследование позволит разобраться в межъязыковых и межкультурных проблемах и предложить такие стратегии перевода, которые помогут переводчику достичь более точных переводов и способствовать более позитивным межкультурным отношениям между Тайванем и другими странами. Данное межкультурное исследование поможет лучше понять, как можно эффективнее продвигать тайваньские товары на русскоязычных рынках.

Ключевые слова: иностранное заимствование; культурный посредник; местное заимствование; переводческая креативность; теория реконтекстуализации; теория Скопос; эквивалентность; энциклопедическое (междисциплинарное) знание. 